\section{Evaluating of viewpoint methodically and formal of Arabic teaching set named as "el-Yâsemîn"}

\section{“el-Yâsemîn” isimli Arapça öğretim setinin biçimsel ve yöntemsel açıdan değerlendirilmesi}

\author{
Haci Yilmaz ${ }^{1}$
}

\begin{abstract}
The classical understanding of foreign language teaching in our country cannot be ignored in Arabic as in other languages and it is seen that some of the studies conducted in this field are incomplete or inadequate. Nowadays it is now well understood that language skills are not just the text to be read and written and then translated into the main language. Understanding and speaking skills prevented the learning of the grammar of that language first. For this purpose, language teaching and learning methods have changed in all parts of the world and accordingly materials that can serve the same purpose have begun to be developed. Language learning sets take the first place among them. Because, although the technology has been making dizzying progress, the book is always the first and most important material.
\end{abstract}

This article is about the newest set of Arabic language teaching sets, al-Yasemin, which has been studied in very few educational institutions. In the article, teaching the four skills of the set and teaching grammar methods were examined and suggestions were made for their deficiencies and their successful aspects were put forward.

After the examination, the "handsJasmine" of the teaching kit prepared a modern method, language is extremely successful in

\section{Özet}

Ülkemizde yabancı dil öğretimindeki klasik anlayış diğer dillerde olduğu gibi Arapçada da bir türlü aşılamamakta, bu alanda yapılan bazı çalışmaların da eksik veya yetersiz kaldığ1 görülmektedir. Günümüzde dil becerilerinin sadece okuma ve yazma sonra da okunan metni ana dile çevirmek olmadı̆̆ artık iyice anlaşılmıştır. Anlama ve konuşma becerileri, ilk önce o dilin gramerinin öğrenilmesinin önüne geçmiştir. Bu amaçla dünyanın her tarafinda dil ögretim ve öğrenim yöntemleri değişmiş ve buna bağlı olarak da aynı amaca hizmet edebilecek materyaller geliştirilmeye başlanmıştır. Dil öğrenim setleri bunlar arasında ilk sırayı almaktadır. Çünkü her ne kadar teknolojide baş döndürücü ilerlemeler olmuş olsa da kitap her zaman ilk ve en önemli materyal olma özelliğini korumaktadır.

$\mathrm{Bu}$ makale, Arapça dil öğretim setleri içinde en yenisi olan ve henüz çok az eğitim kurumunda okutulmakta olan "el-Yâsemîn" isimli setin biçimsel ve yöntemsel incelemesini konu almaktadır. Makalede, setin fiziki durumu, dört beceriyi öğretme ve gramer öğretimi yöntemleri incelenmiş ayrıca varsa eksik yönleri için önerilerde bulunulmuş, başarll yönleri de ortaya konulmuştur.

\footnotetext{
1 Dr. Öğr. Üyesi, Ankara Yıldırım Beyazıt University, İnsan ve Toplum Bilimleri Fakültesi, Doğu Bilimleri ve Edebiyatları, Arap Dili ve Edebiyat1 Anabilim Dalı, hylimaz@ybu.edu.tr
} 
teaching their skills, visual and rich use of visual material, students in easily can carry size, the price is quite reasonable, more than equal to those who want to learn Arabic in Turkey conditions We believe that it can provide more benefits. In addition, we believe that it will increase the benefits of the teaching set by rearranging the set within the framework of the suggestions we have made in the set and making some additions and subtractions if necessary.

At the end of the examination and determinations we made, it is concluded that the kitap al-Yasemin lar Arabic instruction set proves that it can learn Arabic at A1, A2 and B1 level, and that it does not require volumes of books.

Keywords: Education; Teaching Set; Arabic; Method; Review.

(Extended English summary is at the end of this document)
Yapılan inceleme sonucu, "el-Yâsemîn" ögretim setinin modern bir metotla hazırlanmıs, dil becerilerinin öğretilmesinde son derece başar1l, görsel ve işitsel materyali kullanma açısından oldukça zengin, öğrencinin kolayca taşıyabileceği ebatlarda, fiyat olarak oldukça makul, Türkiye şartlarında Arapça öğrenmek isteyenlere eşitlerine nazaran daha fazla yarar sağlayabileceği kanaatindeyiz. Belirttiğimiz eksikliklerin giderilmesi ve yaptığımı öneriler çerçevesinde setin tekrar düzenlenmesi faydasını bir kat daha artıracağına inanıyoruz.

Ulaştuğımız bir başka sonuç ise, iki cilt olan "el-Yâsemîn" Arapça öğretim setiyle A1, A2 ve B1 düzeyinde Arapça öğrenilebileceği ve bunun için ciltler dolusu kitaba gerek olmadığıdır.

Anahtar Kelimeler: Eğitim; Öğretim Seti; Arapça; Yöntem; İnceleme.

\section{Giriş}

Yabancı dil öğretimi, ders kitapları, materyaller ve uygulanan müfredatla birbirine bağlı çok boyutlu bir süreçtir. Yabancı dil öğretiminde sürecin sadece eğitsel boyutu değil aynı zamanda öğrenicinin dili günlük hayatta kolayca kullanabilmesine imkân tanıyan şekliyle öğrenmesi önemlidir. Çünkü günlük hayatta kullanılabilen dil işlevseldir (Demiral-Yavuz, 2016: 133). Yabancı dil eğitimi eskiden beri genellikle okullarda yapılmaktadır. Günümüzde okulların yanı sıra dil laboratuarları ve dilin doğal ortamında da yabancı dil eğitimi yapan kurumlar vardır. Arapça öğretiminde ders kitapları etkin rolünü sürdürmeye devam etmektedir. Öğretim sürecinde sıklıkla kullanılan ders kitaplarının seçimi ve değerlendirmesi çok önemlidir. Her yıl dünyanın dört bir tarafinda Arapça öğretimi ile ilgili ders kitapları hazırlanmasına karşın, öğrencinin ve öğretmenin ihtiyacına uygun kitap seçimi hala büyük bir sorun arz etmektedir. Bu sebeple öğretmen ve öğrenci görüşleri alınarak yapılan ders kitabı değerlendirmeleri kitapların olumlu ve olumsuz yanlarını görebilmek için çok önemlidir (Demirel, 1993: 87).

Karaduman (1992: 320), her ne kadar bir ders kitabının gerek öğrenci gerekse öğretmen için son derece önemli bir destek ve rehber olmasına rağmen, bir programın ana hedeflerini belirlemede tek kaynak olmayacağını, dil öğrenim ve öğretim sürecinin tek bir kitapla başlayıp bitirilemeyeceğini ancak yardımcı olarak kullanılması gerektiği üzerinde durmaktadır.

Doğan (1989: 202), ise Arapçanın yabancı dil olarak öğretiminde bir ders kitabında bulunması gereken özellikleri şöyle sıralamaktadır:

a-Kitap öğrencinin dil düzeyine uygun dil becerilerini kazandırma özelliği taşımalıdır.

b-Konuşmayı anlamayı ve günlük konuşmaları bilinçli olarak dinlemeyi öğretmelidir.

c-Arapçayı doğrudan bir iletişim aracı olarak konuşmayı öğretmeye uygun olmalıdır. 
Yılmaz, H. (2019). “el-Yâsemîn” isimli Arapça öğretim setinin biçimsel ve yöntemsel açıdan değerlendirilmesi. Journal of Human Sciences, 16(3), 857-874. doi:10.14687/jhs.v16i3.5734

d-Öğrencinin kendi isteklerini Arapça olarak etkileyici bir üslupla anlatmasını öğretebilecek teknik özelliklere sahip olması gerekmektedir.

e-Öğrenciye Arap kültürü hakkında yeterli bilgileri kademeli olarak vermelidir.

Yabancı dil öğretimi alanında ders kitaplarının önemine binaen YÖK, ilk defa 2001-2002 yıllında Yabancı Dil Eğitimi Bölümü dahil olmak üzere tüm öğretmen yetiştiren bölümlere "Konu Alanı Ders Kitabı İnceleme Dersi” koymuştur. Bu dersin amacı öğretmen adaylarına mesleğe başlamadan önce ileride kullanacakları kitaplarını tanıma firsatı vermek ve daha da önemlisi onları öğretim durumuna ve öğrenci ihtiyaçlarına en uygun ders kitabını seçme becerisiyle donatmaktır (Yanpar, 1999: 44).

Yabancı dil öğretimi sadece sınıf içiyle sınırlı kalmamalıdır. Çünkü birey, o dili günlük hayatta ihtiyaçlanını karşılamak, diğer insanlarla iletişime geçmek için öğrenmektedir. Öğretmen ve ders odaklı eğitim anlayışı ile dil öğrenimi sadece sınıfta kalır. Öğrenici sınıfta öğrendiklerini farklı kullanabileceği ortamlar bulmalıdır. Özellikle hedef dilin konuşulduğu ülkede yaşanması öğrenici için farklı öğrenim ortamları ve farklı tecrübeler demektir ki bu da öğrenilen her bir dilbilgisi yapısının, kelimenin ve deyimlerin pratikte kullanılması ya da bu türden farklı bir şeylerin öğrenilmesi demektir (Demiral-Yavuz,2016: 138).

Türkiye'de özellikle son yıllarda, Arapça öğretimine devlet ve millet olarak daha fazla önem verildiği çok açık bir şekilde görülmektedir. Bu durum, söz konusu dilin öğrenilmesini zorunlu kılan siyasi, ekonomik ve sosyolojik sebepler yanında Türk insanının yabancı dil öğrenmeye karşı olan bakış açısının da değişmesiyle yakından ilgilidir. Çünkü önceleri mollaların ve din adamlarının dili olarak kabul edilen ve halkın öğrenmekte çok zorlandığı buna bağlı olarak da yeterli ilgiyi göstermediği Arapça, artık diğer yabancı diller gibi öğrenilmesi gerekli diller arasına girmeyi başarmıştır. Buna bağlı olarak da yeni ve daha faydalı materyaller geliştirilmiştir. Bunların başında dil öğretim setleri gelmektedir. Özellikle yurt dışı kaynaklı olan bu setlerden her yıl birkaç tane görmek mümkün olmaktadır. Bir kısmının ticari amaçlarla hazırlandığı anlaşılan bu setlerin, ilgililerce ayrıştırılması ve en faydalı olan setin ortaya konulması gerekmektedir. Şüphesiz bu, uzun deneme ve incelemeler sonunda gerçekleşebilecek bir durumdur.

Bu makaleye konu olan "el-Yâsemîn” seti hakkında henüz herhangi bir çalışma yapılmamıştır. Daha yeni okutulmaya başlayan setin yöntemi ve konuları ilgililer tarafindan merak edilmektedir. Çünkü her ne kadar hiçbir kitap mükemmel olmasa da en az hatalı ve en çok faydalı kitabı seçmek herkesin ortak arzudur. Bu amaçla bu setin inceleniyor olması bu konudaki birçok soruya da cevap olacak sonuçları içermesi bakımından önem arz etmektedir.

Çalışma, setinöğretim yöntemlerini ortaya koymayı, varsa eksik yönleri için önerilerde bulunmayı, avantajlı olan yanlarını tespit etmeyi, setin başka bir yardımcı materyale ihtiyacı olup olmadığını belirlemeyi, kitapla ilgili merak edilen hususları açıklamayı ve Arapça eğitim veren kurumlardaki öğretmenlere yol göstermeyi amaçlamaktır.

Makale, "el-Yâsemîn” isimli Arapça eğitim setinin “Alıştırma Kitabı” ve "Öğrenci Kitabı” ile sınırlandırılmıştır.

Bu çalışmamızda, ülkemizde en son kullanılmaya başlayan bu setlerden "el-Yâsemîn" isimli set, yöntemsel açıdan ele alınmış ve enine boyuna incelenerek Türk öğrencilere ne kadar yarar sağlayabileceği, dört beceri öğretiminde hangi metotlanı kullandığı, gramer konulanı ve interaktif yönleri üzerinde durulmuştur. Setin faydalı yönleri ortaya konulurken eksik tarafları içinde önerilerde bulunulmuştur.

Türkiye'de 1992-2017 yılları arasında kullanılan bütün eğitim setleri hakkında lisansüstü çalışmalar yapılmıştır. Bu çalışmaların neleri kapsadığı ve ne sonuçlar alındığı belirlenmiştir (Özcan, vd., 2015: 183). Bu setlerden sadece "el-Arabiyye beyne Yedeyk" isimli setin lisansüstü çalışması, Gazi Üniversitesi, Eğitim Bilimleri Enstitüsü’nde Reşit Deniz tarafindan devam etmektedir. 


\section{Problem}

Ders kitapları, öğretmenin ne öğreteceğini öğrencinin ise ne öğreneceğini önemli ölçüde etkilemektedir. 2017 yllında eğitim sahasına çıkan "el-Yâsemîn" isimli set eğitim kurumlarında okutulmaya başlanmıştır. Bu çalısmada, bu setin Arapça eğitiminde dört dil becerisini geliştirmekte yararlı olup olmadığı, yararlıysa ne kadar yararlı olduğu, bu becerileri ve dilbilgisi konulannı verirken benimsediği yöntemler, setin yardımc1 materyallerinin ne kadar etkili olduğu ve yöntemi ortaya konulmaya çalışılmıştır.

\section{Yöntem}

$\mathrm{Bu}$ bölümde araştırmanın modeli, evren ve örneklemi, verilerin toplanması ve analizi bilgilerine yer verilmektedir.

\subsection{Araştırma Modeli}

Araştırmada nitel araştırma yöntemlerinden doküman analizi ve literatür değerlendirmesi kullanılmıştır. Öncelikle yurt içi ve yurt dışında yabancı dil öğretimi, öğrenen özerkliği, Türkçenin yabancı dil olarak öğretimi, ders dışı öğrenme ortamları, ders dışı dil öğrenme ortamları ile ilgili yer alan tez, makale, kitap ve bildiriler taranmış, bunlardan elde edilen bilgiler düzenlenmiştir.

Araştırmada, "Karma Model” kullanılmıştır. Karma model araştırma, araştırmacının yapmış olduğu araştırmasının bir aşamasında ya da araştırma süreçlerinin iki ya da daha fazla aşaması boyunca hem nicel hem de nitel araştırma yaklaşımlarını karılması şeklinde ifade edilebilir (Balcı, 2009: 49).

\subsection{Evren ve Örneklem}

Bu çalışmanın evrenini Türkiye'de okutulmuş veya hali hazırda okutulan Arapça eğitim setleri, örneklemini ise "el-Yâsemîn" isimli eğitim seti oluşturmaktadır.

\subsection{Verilerin Toplanmas1}

Veriler "el-Yâsemîn" setinin taranması ve çıkan bilgilerin kategorize edilerek bunların analiz edilmesiyle elde edilmiştir. Ayrıca elde edilen bu veriler başka setler ve kitaplarla da bazı yönlerden karşlaştırmaya tabi tutulmuştur. Veriler toplanırken özellikle dört becerinin öğretimi açısından hangi yöntemlerin kullanıldığına dikkat edilmiş ve yöntemlerdeki eksiklikler varsa bunların giderilmesi için önerilerde bulunulmuştur.

\subsection{Verilerin Analizi}

Elde edilen veriler dil becerilerine göre kategorize edilerek ayrıştırılmıştır. Bunların düzeylere uygun olup olmadığı Avrupa Ortak Dil Çerçeve Metni’ne uygun konuları kapsayıp kapsamadığ1 kontrol edilmiştir.

\section{Bulgular ve Yorumlar}

$\mathrm{Bu}$ bölümde araştırmanın alt amaçlarına uygun olarak ortaya çıkan bulgulara yer verilmektedir. Bulguların analizi aşă̆ıdaki inceleme sırasına göre yapılmıştır:

1. Set Hakkında Genel Bilgi

2.Setin Dört Dil Beceri Öğretiminde Kullandığı Yöntemi

3. Sette İşlenen Konular

4. Dilbilgisi Konuları ve Dilbilgisi Öğretiminde Kullanılan Yöntem

5.Alıştırma Kitabı

6. Setin İnteraktif Avantajları 


\subsection{Set Hakkında Genel Bilgi}

Set, “Öğrenci Kitabı” ve“Alıştırma Kitabı” olmak üzere iki kitaptan oluşmaktadır. Her ikisi de hemen hemen aynı kalınlıkta ve aynı ebattadır.

\subsection{1. “el-Yâsemîn” İsimli Setin Öğrenci Kitabı'nın Genel Tanıtımı}

Kitabın Adı: el-Yasemin

Alt Başlığı: Silsile fî Ta'lîmi'l-Luğati'l-Arabiyye lin-Nâtıkîne bi-Ğayrihâ

Yazar1 : Muhammad Bahgat Kanafani

Yayın Yilı : 1. Bask1, 25 Mart 2017

Yayınevi : Al Yasameen Yayınlar1-Dubai, UAE

Ünite Sayıs1: XV

Sayfa Say1s1: 240

Diğer Özellikleri: Karton kapak, kuşe kağıda basılı, 21X28 cm. ebadında, seslendirmeli.

Kitabın Düzeyi: A1, A2, B1

\subsection{2. “el-Yâsemîn” İsimli Setin Alıştırma Kitabı'nın Genel Tanıtımı}

Kitabın Adı: el-Yasemin

Alt Başlı̆̆1 : Silsile fî Ta’lîmi'l-Luğati'l-Arabiyye lin-Nâtıkîne bi-Ğayrihâ

Yazar1 : Muhammad Bahgat Kanafani

Yayın Y1l1 :1. Bask1, 25 Mart 2017

Yayınevi :Al Yasameen Yayınlar1-Dubai, UAE

Ünite Sayısı: XV

Sayfa Sayıs1: 272

Diğer Özellikleri: Karton kapak, kuşe kâğıda basılı, 21X28 cm. ebadında, seslendirmeli.

Kitabın Düzeyi:A1, A2, B1

\subsubsection{Fiziksel Tanımlama}

“Öğrenci Kitabı”nın kartondan olan sağ kapağı üzerinde setin ismi mavi renkle Arapça ve İngilizce olarak yazmakta, dünya haritası ve iki tane de Arap kültürünü simgeleyen bina resimleri bulunmaktadır. Sol kapakta ise, "yasemin" çiçeğinin isminin Farsçakökenli olduğundan, setin parçalarının günlük hayattan seçildiğinden, setin konuları işleme yönteminden, öğrenci ve öğretmen ve alıştırma kitabının özelliklerinden ve setin görsel ve işitsel özelliklerinden bahsedilmektedir. Öğrenci kitabı, ilim adamlarının set için söyledikleri sözlerle başlamaktadır. Daha sonra setin öğrencilere sunduğu olanaklardan bahsedilmiş ve içerdiği bölümlerin kısa tanıtımları yapılmıştur. Bu bölümün hemen arkasından ayrıntılı olarak içindekiler kısmı gelmekte ve burada onbeş ünitenin içeriği verilmektedir. Güzel cildi, kalınlık olarak ideal (240 sayfa) oluşu, boyutlarının uygun oluşu ve ofset baskısı kitabın fiziksel tanımlamasında öne çıkan unsurlardır. Ayrıca kitapta kullanılan yazı, resim ve çizimler genel ahlak kurallarına uygundur. 
Yılmaz, H. (2019). “el-Yâsemîn” isimli Arapça öğretim setinin biçimsel ve yöntemsel açıdan değerlendirilmesi. Journal of Human Sciences, 16(3), 857-874. doi:10.14687/jhs.v16i3.5734

\subsection{4. İç Yapı ve Düzen}

Kitabın iç sayfaları görsel olarak çok zengin olup, resim, fotoğraf, harita, şekil, grafik farklı renkler, kelime oyunları ve deneme sınavları bulunmaktadır. İçeriğin görsel anlamda oldukça zengin olduğu gözlemlenmektedir.

Kitapta öğrencilerin üniteleri daha rahat bulması için her ünite başlı̆̆ sayfası için ayrı bir renk tonu kullanılmıştır. Bu sayfa aslında ünitenin hem görsel hem de yazınsal anlamda bir özeti şeklindedir. Çünkü burada ünitede işlenecek konuların ayrıntılı bir dökümü verilmekte, ayrıca görsel olarak da özellikle animasyonlarla konuda geçecek olan yapılar önceden verilerek öğrencinin zihinsel olarak derse ve üniteye hazırlanması sağlanmaktadır. Bu sayfadaki animasyon resimlerinin konunun içeriğini yansıtma başarısı gerçekten takdire şayandır. Bu tanıtım sayfaları iki sayfayı geçmemektedir. Üniteler düzen olarak gayet güzel ve anlaşılır bir yapıdadır. Sette her aktivite için ayrı bir ikon kullanılmıs ve bu ikonlar kitabın tanıtımının yapıldığ jenerik kısmında gösterilmiştir. Setin aktivitelerini simgeleyen ikonlar tablo-1' deki gibidir.

$\mathrm{Bu}$ tabloda en dikkat çekici aktivite, hiç şüphesiz bulmaca ikonuyla gösterilen “"لعبة تعليمية" yani “öğretici oyunlar” bölümüdür. Çünkü ülkemizde

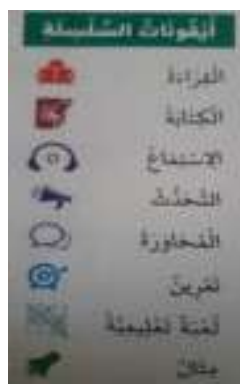

Tablo- 1 y1llarca okutulan "Silsiletu'l-Lisan" seti ile, "el-Arabiyye beyne Yedeyk" ve "el-Arabiyye li'l-Hayat" setleri gibi önemli setlerde bu bölüm bulunmamaktadır. Bu da öğretim setinin artı yönlerinden biri olarak görülmelidir. Bu konuda kitabın arka kapağında sonunda ayrıntlı bilgi verilmiştir. İlerleyen sayfalarda bu ayrnntıları bulabilirsiniz.

Tablo-1'de dilbilgisi için bir ikon görülmemektedir. Ancak yine kitabın giriş sayfasından, dilbilgisi için ةielo bulunduğunu öğreniyoruz. Ayrıca wis. bulunduğu, ifadesini yine aynı bölümden öğrenmekteyiz.

“el-Yâsemîn” isimli Arapça öğretim seti, dil öğretiminde, Avrupa Ortak Başvuru Metni’ne göre üç düzey olarak hazırlanmıştır. Bunlar; A1, A2 ve B1' dir. Yukarıda da kısaca bahsedildiği gibi kitap on beş üniteden meydana gelmekte ve her düzeyde beş dersten oluşmaktadır. Her düzey sonunda öğrencinin bilgilerini sağlamlaştırması ve pekiştirmesi için seviye belirleme sınavı ve konularda geçen bilgileri hatırlatmak amacıyla öğretici oyunlar bulunmaktadır. Ünite sonlarındaki seviye tespit sinavları, dört ya da beş farklı sorudan oluşan okuma anlama, dört ya da beş sorudan oluşan dinleme, iki ya da üç sorudan oluşan yazma ve dört ya da beş sorudan oluşan konuşma bölümlerinden meydana gelmektedir. Bütün becerilerden her düzey sonunda sınav yapılması set için bir avantaj olarak kabul edilmelidir.

Dinleme bölümleri tablo-1'de olduğu gibi kulaklık işareti ile gösterilmiştir. Kulaklık işaretinin ortasındaki rakam dinleme dosyasının numarasını belirtmekte olup öğrenci isterse bu numara ile istediği zaman bu dosyaları indirerek dinleyebilmektedir. Dinleme metinleri okunan parçalarla ilgili olabildiği gibi tamamen farklı bir dinleme metni de olabilmekte bazen de dinleme alışturmaları şeklinde üç farklı şekil olarak karşımıza çıkmaktadır. Öğrenciler bu dinleme metinlerinin ses kayıtlarına www.alyasemeen.net ve www.iarabi.orgsitelerinden ulaşabilmektedirler.

Okuma -anlama bölümleri, dinleme bölümlerinden önce veya sonra gelebilmektedir. Çünkü çoğu zaman okuma ve dinleme metinleri farklı metinlerden oluşmaktadır. Okuma-anlama bölümlerinin arkasından öğrencilerin okunan parçayı ne kadar anladıklarını test eden alıştırmalar bulunmaktadir. 
Yılmaz, H. (2019). “el-Yâsemîn” isimli Arapça öğretim setinin biçimsel ve yöntemsel açıdan değerlendirilmesi. Journal of Human Sciences, 16(3), 857-874. doi:10.14687/jhs.v16i3.5734

Yazma öğretimiyle ilgili bölümlerde kolaydan zora doğru izlenen bir yolla önce harf sonra kelime sonra cümle ve en sonunda küçük bir paragraf yazma şeklinde farklı aktivite ve alıştırmalarla öğrencinin yazma becerisini geliştirilmektedir. Setin yazma becerisine diğer becerilerden daha az yer ve verdiği gözlenmişse de verilen bu aktiviteler bu düzeydeki öğrenciler için tarafımızca da yeterli gözükmektedir.

“Örnek” ikonu altındaki bölümde ise o konuda işlenen dilbilgisi konusuyla ilgili farklı örnekler verilerek ilgili kısımlar renkli yapılarak öğrencilerin bu noktalara yoğunlaşmaları amaçlanmıştır.

Bu bölümlerden sonra beşinci dersin yani o düzeyin bitimine doğru öğretici oyunlar yer almaktadır. Bu oyunlardan amaç, öğrenciyi hem eğlendirmek hem de konuda geçen ve bilmesi gereken kelime ve kalıpları ona tekrar hatırlatmak olmalıdır. Daha önceki öğretim setlerinde görmediğimiz bu bölüm, bir nevi bu beş derslik düzeyin özeti şeklindedir.

Düzeyin en sonunda o düzeyde elde edilen tüm becerileri kapsayan kapsamlı bir sınav bulunmaktadır. Bu sınavın içeriğine yukarıda değinmiştik. Öğrenci için oldukça yararlı olan bu bölümü, ülkemizde daha önce okutulan "el-Arabiyye li'l-Hayat" ve "el-Arabiyye beyne Yedeyk" serilerinde," إِنْتَبْرْ نَفْسَكَك -kendini test et-"başlığ1 altında görmüştük. Ancak buradaki fark, bu sette dört becerinin ayrı ayrı sınavla ve kapsamlı bir şekilde test edilmiş olmasıdır ki bu da setin dört beceriye verdiği önemi ortaya koymaktadır.

Öğrenci kitabındaki B1 düzeyinin sonunda, artık ana konular ve sınavlar bitmiş sıra eklere gelmiştir. Kitapta bu bölüm "Ekler" başlı̆̆1 altında değil, direkt olarak verilmiş ve bu sayfalar numaralandırılmamıştır. Burada ilk olarak, Arap devletlerinin kültürel haritası başlğg altında iki sayfadan oluşan bir bölüm vardır. Arap devletlerinden birer kare fotoğraf olup bu fotoğraflar, ait oldukları ülkelerin en belirgin özelliklerini yansıtmaktadır. Örneğin; Mısır için piramitler veya Suudi Arabistan için Kâbe'nin fotoğrafi gibi.

Yukarıdaki bölümden sonraki ikinci ek sayfasında ise iki tablo bulunmaktadır. Bu tabloların ilkinde "başlğ̆1 ile Arapça temel dilbilgisi kuralları verilmektedir. Burada; kelime, fiiller, merfûât, mansûbât, mecrûrât birer örnekle çok kısa olarak özetlenmiştir (Tablo-2).

İkinci tabloda ise, Arapçadaki irab alametleri yine birer örnekle

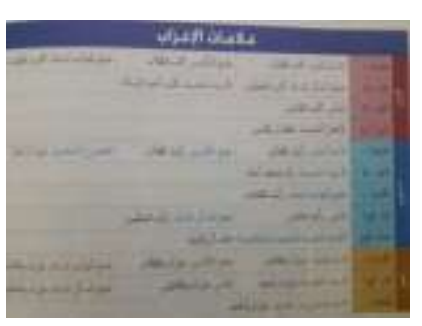
gösterilmiştir (Tablo-3). Bu iki tablo, konuların özetlemesi ve fotoğrafinın çekilerek istenildiği zaman bakılabilmesi yönleriyle öğrenci için oldukça faydalı

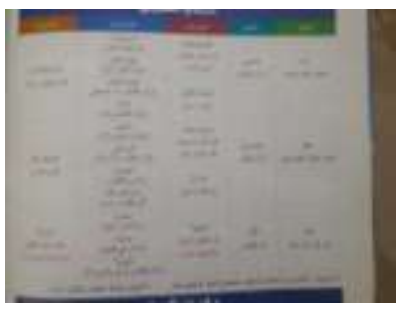

Tablo- 2 olacaktır.

Tablo- 3

Kitabın son sayfasında kitapta geçen, setin bizce de en önemli artısı olduğunu düşündüğümüz "öğretici oyunlar" hakkında ayrıntılı ve açıklayıcı bilgiler bulunmaktadır. Bu oyunlara internetten ulaşılabilmekte olup, ders dişı ortamlarda öğrenciler rahatlikla bunlardan faydalanabilmektedirler. Bunlar; 240 karttan oluşan "kelime kartlarr”. Bu oyunda kartlardaki kelimeler üç düzeyi kapsayacak şekilde düzenlenmiş ve kolaydan zora doğru bir yöntem uygulanmıştır. Her kart taşıdığı kelimenin türeyiş biçimine göre farklı renklere boyanmış ve her kartın arka tarafinda karttaki kelimenin fotoğrafi bulunmaktadır. Bu konuda öğrenciler isterlerse kalimat.alyasameen.net adresinden daha geniş bilgi alabileceklerdir. 
Ayrıca harfler ve yeni kelimelerin öğrenilmesinde "ebced" adlı oyun ve eğlence kartları da bulunmaktadır. Bu kartlar 169 adettir. Bu konuyla ilgili bilgiler abjad@alyasameen.net adresinden edinilebilir.

İnternet yoluyla ulaşılabilecek başka bir oyun da "hurufu'l-arabiyye”'dir. Burada yirmi sekiz kart bulunmakta ve her kartta her harf için bir kelime bulunmaktadır. Bunların seslendirmelerine öğrenci yine internetten kartlardaki numaralar sayesinde huruf.alyasameen.net sitesinden ulaşabilmektedirler.

"kul lî” isimli kart oyunu doksan karttan oluşmakta ve Arapça

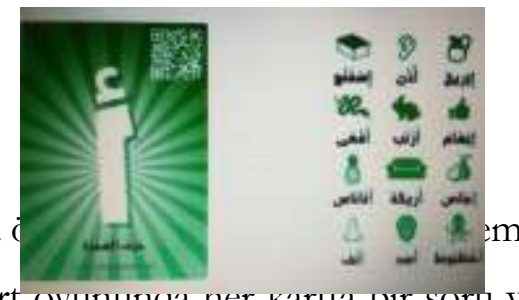

Yüz yirmi karttan oluşan "ene indi ve men indehu” isimli kart oyununlda ner kartud DIr soru ve bir cümle bu hazinesinin çoğalmasına yardımcı olmak için tasarlanmıştır. İndi.alyasameen.net

Bir başka oyun "bediyhe” 'dir. Bu oyun hem eğlenmek ve hem de öğrenmeye yönelik olup elli beş karttan meydana gelmektedir. Her iki kart arasında ortak bir şekil bulunmaktadır. Bu kart oyunu da kelime öğrenmeye yöneliktir ve badiha.alyasameen.net internet adresinden ulaşılabilir.

Kitabın sayfa numaraları rakamla verildiği gibi harflerle de verilerek sayıların öğretilmesine teşvik edici bir tutum izlenmiştir.

Son olarak jumal.alyasameen.net sitesinde bulunan "cümel" oyunundan bahsetmek gerekirse oyun, altmış karttan oluşmakta ve bu kartlar filler, isimler, sıfatlar ve harfler şeklinde bölümlere ayrılmıştır. Bu oyun tamamen öğrencinin cümle kurmasına yönelik hazırlanmıştır. Bu kartlarla bin cümle kurulabilmektedir.

\subsection{Setin Konuları İşleme ve Dört Dil Becerisi Öğretiminde Kullandığ1 Yöntem}

Dil öğretiminin temel amacı dil becerilerinin öğrenciye kazandırılmasıdır. Bunun için doğru yöntem ve doğru materyal seçimi oldukça önemlidir. Özellikle dil becerilerinin hangi sırayla ele alınması gerektiği, zaman ve etki açısından önemlidir. Son yıllara kadar ülkemizde okuma-anlamayı ön plana alan bir yöntemle dil öğretimi yapılmaktaydı. Buna medrese ekolü de denilmekteydi. Bu yöntem yüzylllarca denendi ama istenilen sonuç bir türlü alınamadı. Çünkü dinleme ve konuşma becerileri olmadan dil ögretimi yarım kalmakta tek ayaklı bir adam gibi olmaktaydı. Bunu destekleyen ve sadece okuma-anlama yöntemi üzerinde duran bir çok eski ve hatta yeni metotoloji kitapları bulunmaktadır (Hûlî, 2000). Ancak zamanla bu yöntem iflas etmiştir. Bunun yerine kanaatimizce de uygun olan dört beceriyi aynı anda ve belirli bir yöntem içinde geliştirmekle ve gramere boğulmadan yabancı dille yüz yüze gelinerek yabancı dil öğrenilmektedir. Ancak burada da başka bir sorunla karşılaşılmıştır; dört becerinin hangisiyle başlanmalı ve hangi yöntemler kullanılmalı? Bizim de en doğru sıralama olduğuna inandığımız dinleme, konuşma, okuma ve yazma şeklindeki bir sırlamayı birçok yazar desteklemektedir (el-Fuzan, 2015: er-Rehban vd. , 2017: Özcan vd., 2018: Demirel, 1993). Çünkü bu sıralama insan fitratına en uygun sıralamadır.

Bu bölümde "el-Yâsemîn" isimli öğretim setinin dört beceriyi öğretme metodu ve konuları işleme yöntemi ele alınacaktır. Bunun için kitaptaki dört beceriyle ilgili tüm aktiviteler taranmış ve aşağıdaki bilgilere ulaşılmıştır.

\subsubsection{Dinleme Becerisini Geliştirme Aktiviteleri ve Kullanılan Yöntem}

Ülkemizdeki yabancı dil öğretiminde dinleme becerisinin, dil öğrenmenin ilk ve en etkili becerisi olduğu artık şüpheye yer bırakmayacak şekilde nihayet anlaşılmıştır. Dolayısıyla bundan sonraki programların dinleme becerisini ön plana çıkaran içerikleri barındıracağını tahmin etmek zor olmasa gerektir. Bunun için bu beceriyi ilk sıraya alan kitapların da önem kazandığ bir döneme girilmiş bulunmaktadır. Bu bağlamda incelediğimiz "el-Yâsemîn" isimli öğretim setinin dinleme becerisini kazandırmak için nasıl bir yöntem izlediğine bakalım. 
Yılmaz, H. (2019). “el-Yâsemîn” isimli Arapça öğretim setinin biçimsel ve yöntemsel açıdan değerlendirilmesi. Journal of Human Sciences, 16(3), 857-874. doi:10.14687/jhs.v16i3.5734

“el-Yâsemîn” setinde bizce en dikkat çeken nokta, ünitelerin birçoğunun dinleme becerisiyle başlamasıdır. Bu durum daha A1 düzeyinin ilk dersinden başlamakta ve B1 düzeyinin son iki ünitesi hariç tüm set boyunca devam etmektedir. Bu noktada kitap bizce de doğru yöntemi seçmiş ve önce dinlemeyle başlamıştur. Yukanda değinildiği gibi dinleme bölümleri kulaklık işareti ile gösterilmekte ve kulaklığın içindeki rakam da internetten dinleme dosyasının numarasını işaret etmektedir. Dinleme Cd 'si olmayan setin, dinleme metinleri ana dili Arapça olanlar tarafindan seslendirilmekte ve konuşmanın geçtiği doğal ortam sesleri de zaman zaman yansıtılmaktadır. Dinleme metinlerinin seslendirilmeleri önceleri yavaş daha sonraları kademeli olarak daha hızlı ve doğala en yakın haliyle okunmuştur. Dinleme dosyaları internetten www.iarabi.org sitesinden indirilebilmektedir.

Her ünitede yaklaşık sekiz-dokuz dinleme bölümü bulunmaktadır ki bu oldukça yeterli bir

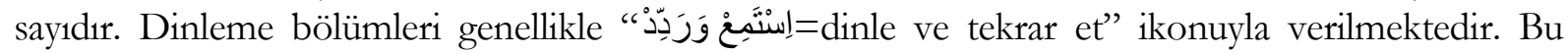
uygulamanın, dinleme-konuşma ikilisinin aynı anda gelişmesi için önemli bir uygulama olduğunu düşünüyoruz. Bunun dişında “ "استمع ولاحظ/استمع و اقرأ/ استمع واكتب=Dinle ve dikkat et/dinle ve oku/dinle ve yaz" şeklinde talimatlar da bulunmaktadır. Bunlar, setin dinleme becerisini diğer tüm becerilerin önüne koyduğu ve her beceriden önce dinleme yaptırarak o beceriyi kazandırmaya çalıştı̆ını göstermektedir.

Sonuç olarak, setin dinleme metinlerinin açık ve anlaşlır olduğu ve sette yeterince dinleme bölümlerine yer verildiği, dinleme metinlerinin sadece kitaptaki okuma parçaları ya da diğer aktivitelerle sınırlı kalmayıp tamamen farklı konulardan da oluştuğu söylenebilir. Bu, öğrencinin farklı ve görmediği metinleri dinleyerek anlama becerilerini geliştirmekte bizce çok önemli bir yöntemdir. $\mathrm{Bu}$ anlamda dinleme becerisinin öğretilmesinde setin kesin bir başarısından söz edilebilir.

\subsubsection{Konuşma Becerisini Geliştirme Aktiviteleri ve Kullanılan Yöntem}

"el-Yâsemîn” Arapça öğretim seti konuşma becerisi için iki farklı aktivite sunmuştur.

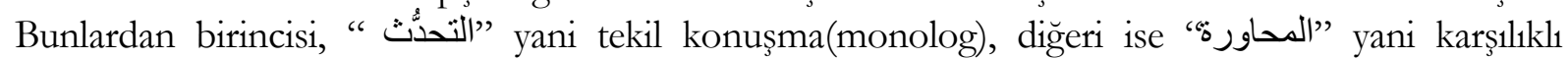
konuşma (diyalog)' dır. Bundan önce eğitim kurumlanımızda okutulan iki önemli set olan "elArabiyye beyne Yedeyk" setinde sadece "الكلام" başlığ1 altında monolog verilmekteyken, "elYâsemîn" den önce çıkan "Silsiletu'l-Lisan" isimli öğretim setinde ne monolog ne de diyalog bölümleri bulunmaktadır. Bu sette konuşma becerisi için verilen aktivite sadece ünite başlarındaki أجب عن الأسئلة “ bölümündeki iki-üç soru ile okuma parçalarından sonra parçayla ilgili "(انظر وأجب" "التالية " bölümündeki üç-dört sorudan ibaretti. Bu durum göz önünde bulundurulduğunda "elYâsemîn" setinin konuşma becerisini geliştirmeye yönelik önemli iki aktivite sunması setin becerileri öğretme yöntemi açısından önemini bir kez daha ortaya koymaktadır.

İncelediğimiz kadarıla kitap, bütün düzeylerde konuşma becerisini geliştirmeye yönelik alıştırmalar vermektedir. Set, her ünitede ortalama altı monolog sekiz tane de diyalog etkinliği ile gerçekten bu anlamda göz doldurmaktadır. Karşılıklı konuşma metinleri ünitenin konusuyla ilgili olduğu gibi sınıf içindeki bir durum veya eşya hakkında da olabilmekte, ilerleyen düzeylerde de "Şehrinizin en meşhur kişileri kimlerdir, neler yapmışlardır?" gibi geçmişte yaşanan ve diğer öğrencilerin bilmediği bir olayın anlatılması istenmektedir.

Sonuç olarak, setin konuşma öğretimi bakımından çok başarılı olduğu söylenebilir. Basit diyaloglardan başlayarak karmaşı metinlere doğru bir seyir izlemesiöğretim yöntemi açısından önemlidir. En basit seviyede bile öğrenciye konuşmaya teşvik etmesi hatta zorlaması öğrencinin dilinin çözülmesi ve konuşamama korkusunu yenmesi açısından fevkalade önemlidir.

\subsubsection{Okuma Becerisini Geliştirme Aktiviteleri ve Kullanılan Yöntem}

A1 düzeyinin ilk dersinde daha çok dinleme ve harflerin yazımına önem verilmiş doğal olarak herhangi bir okuma parçası konulmamıştır. İkinci derste basit tanışma metniyle ilk okuma metni verilmiştir ki bu durum diğer öğretim setlerinde de hemen hemen aynı şekildedir. Setin 
okuma parçalarında yeterince yeni kelime öğretmektedir. Kelimelerin benzerleri verilerek birbirinden ayırt edilmeleri için okuma aktiviteleri konulmuştur (s.43) ki bu daha ilk ünitelerde başlamaktadır. Öğrencinin ileride yazma ve okuma hatalarını en aza indirebilmesi için bu alıştırmaların çok faydalı olduğu kesindir.

Okuma parçalan, içeriğe uygun olarak resim ve fotoğraflarla desteklenmiş (s.44, 45) böylelikle öğrencinin henüz okuma parçasını okumadan önce parça hakkında iyi kötü bir fikir sahibi olması sağlanmıştır.

Okuma parçaları ünitenin konusuna ve dilbilgisinde verilen kurala uygun olarak hazırlanmış $(40,59)$, dilbilgisi kurallarının geçtiği kelimeler okuma parçalarında sarı ile boyanmıştır. Metinler öğrencinin seviyesine uygun düzenlenmiş ve onun ilgisini çekecek konular seçilmiştir. Parçalardaki terkipler ve bağlaç kullanımı günlük hayatta öğrencinin kullanabileceği niteliktedir.

A1 düzeyinin beşinci dersinden itibaren artık diyalog ve bir paragraftan oluşan küçük okuma parçalarının yerini uzun metinler almış olsa da bu metinlerin içerik ve kelimeleri A1 düzeyini geçmemektedir. Burada zannımızca öğrencileri A2 ve B1 düzeyindeki uzun ve zor parçalara hazırlamak amacıyla uzun parçalar verilmiştir. Öte yandan ünitelerin okuma parçaları açısından zengin olduğunu, her ünitede 4-5 tane irili ufaklı okuma metninin bulunduğunu söylemekte de fayda olduğunu düşünüyoruz. Çünkü okuma parçalarının bu düzeyde bu kadar yoğun olması öğrencinin yabancı bir alfabeyle okumasını sağlamlaştıracağı gibi kelime hazinesini de geliştirecektir.

A2 düzeyi okuma becerisi ile ilgili kitabın yine aynı yöntemi kullandığ1 yani kolaydan zora doğru bir yöntem uyguladığı görülmektedir. Diyalogun azaltıldığı ve karmaşık yapıların ve harfi cerli önemli fiillerin bolca kullanıldığı uzun okuma metinlerine bu düzeyde çokça rastlanmaktadır. $\mathrm{Bu}$ bölümde bazı okuma parçalarında öğretilen yeni kelimelerin farklı bir renkle boyanarak dikkat çekmek istenildiği görülmektedir. Daha sonra okuma çözümleme bölümünde bu kelimelerle öğrenciden cümle kurması istenmektedir. $\mathrm{Bu}$ da öğrenciye kelime kazandırmak için güzel bir yöntem olarak görülebilir.

B1 düzeyi okuma metinlerinin daha teknik ve güncel olduğu söylenebilir. Örneğin, Araplarda erkek ve kadınlar için giyim modası, seyahat, buluşlar, Arap yazısı gibi. Artık bu düzeyde parçalar çok uzun ve zor yapılar ve bağlaçlar içermektedir. Bu aşamadaki bazı metinlerin bu düzeyin üzerinde olduğu söylenebilir. Ancak bunların öğrenciyi daha karmaşık ve zor metinlere hazırlamak için konulmuş olduğunu düşünmekteyiz.

Sonuç olarak, bu öğretim setinde yeterince okuma parçası kullanıldığı, parçaların istenildiği kadar yeni kelime öğrettiğ̈i, okuma parçalarının güncel konulardan seçilerek öğrencileri Arapçaya ve okumaya teşvik ettiği söylenebilir. Kitabın bu beceride kolaydan zora, azdan çoğa, seyrekten yoğuna doğru bir yöntem izlediği, okuma parçalarındaki kelimeleri öğretmek için değişik aktiviteler sunduğu, okuma parçalarının dinleme metinleri ve resim ve fotoğraflarla desteklenerek daha kalıcı olmasına çalışıldığı görülmektedir.

\subsubsection{Yazma Becerisini Geliştirme Aktiviteleri ve Kullanılan Yöntem}

Sette yazma aktiviteleri daha birinci derste dinleme becerisine paralel olarak harfleri dinleyip yazmayla başlamaktadır. Özellikle dinlenilen metinlerin yazılması şeklinde görülen bu becerinin aktiviteleri; boşluklan doldurma, panodaki eksikleri tamamlama, okuma metinlerinde geçen yeni kelimeleri deftere yazma, öğretmenin okuduğu bir metni harekeleme, dilbilgisi konusuyla ilgili örnek yazma, işlenen yeni bir kalıpla kendinden bir cümle kurma ve verilen bir resmi niteleyen bir cümle yazma gibi değişik şekillerde karşımıza çıkmaktadır. Yazma aktiviteleri açısından setin A1 düzeyinde, çok doğru bir yöntemle, önce kelime sonra da cümle yazdırdığını görmekteyiz. Yani parçadan bütüne doğru bir yöntem izlenmiştir. 
Yılmaz, H. (2019). "el-Yâsemîn” isimli Arapça öğretim setinin biçimsel ve yöntemsel açıdan değerlendirilmesi. Journal of Human Sciences, 16(3), 857-874. doi:10.14687/jhs.v16i3.5734

A2 düzeyinin ilk ünitesinden itibaren paragraf yazma çalışmalarının başladığ görülmektedir(s.88). Burada ünite konusuyla ilgili küçük bir paragraf yazılması istenmektedir. Ünitelerdeki beceri dağlımlarında, dinleme ve okumadan sonra dört-beş aktivite ile yazma becerisinin geldiği görülmüştür. Bu düzeyin bazı yazma aktivitelerinde "el-Arabiyyeli'l-Hayat" serisinde olduğu gibi belli konu başlıkları verilerek bunlar etrafinda bir mektup ya da üç küçük paragrafi geçmeyecek şekilde bir kompozisyon yazılması istenmekte ve öğrenci uzun kompozisyon yazımlarına hazırlanmaktadır. Bu aşamanın başka bir aktivitesi de yazma becerisini dilbilgisiyle birleştirerek yapılan çalışmalardır. Burada, okuma parçası yazılarak parçada geçen muzari fillerin maziye ya da tam tersi bir işleme tabi tutulması istenmektedir.

B1 düzeyi yazma etkinliklerinde artı öğrencinin kendi zihninden ve uzun bir metin yazmas1 beklenmektedir. Bu metinler, okuma parçalarını özetlemek ya da bir atasözünü açıklamak şeklinde kendini göstermektedir. Bu düzey alıştırmalarından biri de öğrencinin geçmiş zamanda yaşadığı bir anısını anlatmasıdır. Bu etkinlikler, adeta öğrencinin üç düzey boyunca öğrendiklerinin tamamını kullandığı bir arena durumundadır. Çünkü kelime, cümle, dilbilgisi ve kalıp ifadelerin kullandığı yegâne alan, yazma becerisi alanıdır.

Sonuç olarak, sette yazma becerisine diğer aktivitelerden daha az yer verilmiştir. Bu üç düzey için bu durum normal de görülebilirse de set için bir eksiklik olarak göze çarpmaktadır. Kanaatimizce setteki yazma etkinliklerde tümevarım yönteminin kullanılması doğru bir yöntemdir. $\mathrm{Bu}$ yöntemde parçadan bütüne doğru ilerlenmekte, örnek olay, sorun ve özel durumlardan hareketle genel kurallara veya sonuçlara ulaşılmaktadır. Bu işlem öğrencilerde dilbilgisi mantığını keşfetmekte ve bilimsel düşünme becerisini geliştirmeye katkıda bulunmaktadır (Altun, 2017: 40).

\section{3. "el-Yâsemîn” Setinde İşlenilen Konular}

"el-Yâsemîn” setinin A1,A2 ve B1 düzeyini kapsadığını ve her düzeyin beşer üniteden oluştuğu hususuna çalışmamızın daha önceki bölümlerinde kısaca değinmiştik. Bu bölümde setin ele aldığ konuları ayrıntılı olarak inceleyecek ve kelime zenginliği, zorluk-kolaylık ve güncelliği bakımından değerlendireceğiz.

Setin her düzeyinin başında düzey A1,A2, B1 şeklinde belirtilmiştir. A1 düzeyinin beş ünitesinin konuları toplu olarak düzey giriş sayfasında ayrıntılı bir biçimde açıklanmıştır. Biz burada konuların düzeye uygun olup olmadığ1 ve yöntemi açısından bakacağız.

A1 düzeyinin ilk ünitesinde alfabenin öğretilmesi hedeflenmiştir. "Elif-Bâ" isimli bu ünite, önce harfler dinletilmesiyle başlamakta sonra harflerin yazımı, benzer harf ve seslere, duyduğu harfi yazmaya sonra harekelere geçilmektedir. Konu işlenirken bütün dil becerilerine yer verilmiş ayrıca oyunlarla desteklenmiştir. Kanaatimizce dikkatli ve düzenli çalışan bir öğrenci için bu ünite ilk aşama için yeterlidir. Çünkü birçok aktivite ve ders dışı oyun kartlarılyla bu ünite kolaylıkla anlaşılacak bir düzeydedir. İkinci ünite "es-Selamu Aleykum” adını taşımaktadır. Ünite ilk bakışta tanışma ve tanıştırma konusunu ele alıyor gözükse de birden ona kadar sayıları, kimlik kartı doldurma, telefon numarası söyleme, Araplardaki erkek-kadın isimleri gibi konuyla ilgili bazı bilgileri de içermektedir. "Ene Edrusu" ismini taşıyan üçüncü ünite, bir önceki konuyu pekiştirecek yeni küçük bir parçayla başlamakta daha sonra yeni filler kullanarak eğitim ve öğretimle ilgili bir paragraflı parçalarla devam etmektedir. Burada eski kelimeler yer yer tekrar edilirken yeni kelimeler de öğretilmektedir. Bu ünitede renkler müennes-müzekker olarak ayrıca verilmiştir. Dördüncü ünite "Ene A'melu" ismindedir. Burada yine dinleme ile başlanmış ve meslek isimleri öğretilmeye çalışılmıştır. Verilen parçalarda sarmal bir bakış açısının belirtilerini görmek mümkündür. Çünkü dördüncü ünitede bile hala tanışma ve kendini tanıtmayla ilgili parçalar ve diyaloglar bulunmaktadır. $\mathrm{Bu}$ diyalogların arasına yeni konuyla ilgili kelime ve terimlerin serpiştirilerek harmanlandığı dikkatler kaçmamaktadır. Bu üniteden itibaren artık konuyla ilgili iki paragraflık okuma ve dinleme parçalara başlamaktadır. Bu ünitedeki parçaların kelime zenginliği ve zorluğu düzeyin biraz üzerinde olsa da kanaatimizce bu durum A2 düzeyine bir hazırlık olarak değerlendirilmiştir. Beşinci ve A1 düzeyinin 
Yılmaz, H. (2019). "el-Yâsemîn” isimli Arapça öğretim setinin biçimsel ve yöntemsel açıdan değerlendirilmesi. Journal of Human Sciences, 16(3), 857-874. doi:10.14687/jhs.v16i3.5734

son ünitesinin konusu "Ailet̂̀" dir. Konu diyaloglarla başlamış ve ilerleyen sayfalarda uzun parçalarla devam etmektedir. Parçaların geçen dört ünitedeki konuları kapsadığını söylemek abartılı olmayacaktır. $\mathrm{Bu}$ ünitede de çok fazla yeni kelime verilmemiş önceki kelimelerin tekrarı benimsenmiştir.

Sonuç olarak, A1 düzeyi parçaları ve konuları düzeye uygun, kelime zenginliği bakımından yeterli, ünite konuları dört beceri aktiviteleriyle öğretilmeye çalışılmış, yeni kelimeler ayrıca verilmemiş ancak parça içlerinde farklı bir renkle işaretlenmiştir. Okuma ve dinleme parçaları sarmal olarak bir önceki üniteleri kapsayan diyalog ve düz metinlerden oluşmuştur. Bu düzeyde, Sarmal Öğrenme Yaklaşımı ${ }^{2}$ nın çok güzel ve başarılı bir şekilde kullanıldığı görülmektedir.

A2 düzeyinde yine beş ünite bulunmaktadır. Bunlar; "Luğatî el-Arabiyye", "Yevmun min Hayatî", "Menzilı̀", "fị Medinetî", "Taâmî" 'dir. Genel olarak bakıldı̆ı̆ında konuların A2 düzeyine uygun olduğu görülmektedir. İçeriklerine baktığımızda diğer setlerdeki aynı konuların klasik alt başlıklarının aksine bir durum olduğu gözlemlenmektedir. Örneğin, ilk ünitede Arapçanın dünya dilleri arasındaki yeri ve önemi ile Arapça konuşan ülkeler yarım sayfalık bir metinle anlatıldıktan sonra dünyada aslı Arapça olan kelimelerin kullanımı ve kullanan ülkelerin hangi kelimeleri kullandıklarını konu alan bir parça yer almaktadır. Bu ve benzeri durumlardan kitabın dili öğretirken Arap kültürünü de öğretmeye olan gayretini görmekteyiz. Kanaatimizce de bir öğretim setinin amaçlarından birinin de o dilin kültürel zenginliğini yansıtacak girişimler olması gerekliliğidir. Düzeyin ikinci ünitesinde çok güncel bir konu ele alınmış ve bir bireyin günlük aktiviteleri daha ünitenin jenerik sayfasında ayrıca verilmiştir. Ancak içeriğe baktı̆ımızda yine diyalog destekli parçaların sadece öğrencinin okul hayatıyla ilgili olduğunu görmekteyiz. Bu ünitede okul dışı faaliyetlerin de yer aldığı parçaların da olmasının daha güzel ve güncel olacağı kanaatini taşımaktayız. Üçüncü ünitede Arap evlerinin özelliklerinden bahsedilmektedir. Değişik ülkelerden Arap evlerinin yapısı, şekli ve konforundan söz edilerek üniteye başlanmıştır. Bu ünitede ev eşyaları ve adres sorma gibi konuyla ilgili alt öğeler de yer almaktadır. Yaptığımız incelemeye göre konu güzel ve kapsamlı bir şekilde incelenmiş, önce küçük sonra daha uzun ve zor parçalara doğru kolaydan zora giden bir metotla parçalar sıralanmıştır. Kelime zenginliği açısından baktığımızda, özellikle uzun parçalarda güncel ve önemli kelimelerin kullanıldığı kolayca fark edilmektedir. Dördüncü ünitede şehir hayatı birçok boyutuyla ele alınmış, düzey öğrencisinin ihtiyacı olan bilgiler fazlasıyla verilmiştir. Trafik işaretleri, adres sorma, genel mekanların isimleri, adres verme gibi konular alt konular olarak işlenmiştir. Diğer ünitelerde olduğu gibi bu ünitede de sıra dışı ve diğer setlerde görmediğimiz kelimeler dikkat çekmektedir. Yeni kelime öğretimi ve tekrar açısından konular oldukça zengindir. Bu düzeyin son ünitesi "Taâmî" isimli ünitedir. Bu ünitede yemekler ve yiyecek isimleri yeterince verilmiş olup ayrıca geçmiş zamanlardaki yeme-içme alışkanlıklarına da değinilmiştir. Yine parçalar kolaydan zora doğru sıralanmıştır.

B1 düzeyinin konuları beş ünite için şöyle sıralanmaktadır: "fił's-Suûk", "İcâzetî", "Risâlet̂", “el-Aklu’s-Selîm fi'l-Cismi’s-Selîm”, "el-Ẩlem”. İlk ünitede çarşı ve alışverişle ilgili yeterince kelime verilmiştir. Konu renkli ve net fotoğraflarla da görsel olarak desteklenmektedir. Ünitede yer alan aktivitelerin hemen hemen hepsinde ünite konusu işlenmektedir. İkinci ünitede, seyahatle ilgili uzun diyalog ve parçalara yer verilmiştir. Verilen okuma parçalarında ünitede işlenen dilbilgisi konusu çok güzel bir şekilde ele alınmış ve konuyla ilgili yerler farklı renkle boyanmıştır. Verilen örnekler ünite konusuyla ilgili olup, hem yeni kelimeler hem de yeni dilbilgisi konusunu içermektedir. Okuma parçaları kalıp ifade ve deyimsel söz öbeklerini barındırmaktadır. Üçüncü ünitede internet ve onunla ilgili alt konular işlenmiştir. Ayrıca mektup ve davetiye çeşitleri de burada örneklerle

\footnotetext{
${ }^{2}$ Bruner'in 1960'ta ortaya koyduğu sarmal öğrenme yaklaşımı (SPR) öncelikle ana terimleri belirlemek ve düşük zorluk derecesinden daha zor ve karmaşık problemlere geçmeyi temellendirmektedir. Her yeni düzeye geçişte ilk düzeyde öğrenilen kavramlar kullanılmaya ve tekrarlanmaya devam edilmekte; bu bakımdan öğrenme süreci kesintiye uğramamaktadır. Öğrenciyi merkeze alan bu eğitim biçimiyle öğrencinin içindeki merak duygusu beslenmekte; planlama yapması, araştırmacı olması ve bulgularını paylaşarak, uygulamasını temellendiriyor(http://www.akasyam.com/egitimde-sarmal-yaklasim-nedir ?).
} 
Yılmaz, H. (2019). “el-Yâsemîn” isimli Arapça öğretim setinin biçimsel ve yöntemsel açıdan değerlendirilmesi. Journal of Human Sciences, 16(3), 857-874. doi:10.14687/jhs.v16i3.5734

tanıtılmaktadır. Dördüncü ünitede sporla ilgili iki parça sunulmuştur. Ayrıca beş duyu ile ilgili diyalog ve parçalara da rastlamaktayız. Ünitenin son taraflarına doğru hastalıklar hakkında ayrıntılı bilgi veren okuma parçaları bulunmaktadır. "el-Âlem” isimli son ünitede dünyadaki birçok konu ele alınmıştır. Öncelikle hayvanlar âleminden bahsedilmekte arkasından su ve suyun dünyadaki önemi, tarih boyunca insanoğlu tarafindan ulaşılan keşiflerin dünya hayatındaki değişikliklere değinen parçalar yer almaktadır.

"el-Yâsemîn” Arapça öğretim setinin konularını genel olarak bakmak gerekirse; setin konu çeşidinin diğer setlerdeki aynı düzey konularından daha az olduğu değerlendirilmiştir. Bundan önceki "Silsiletu'l-Lisan" setinin aynı düzeylerinde, sosyal hayat, ulaşım, iletişim, kültür, savaş ve barış, hava kirliliği, insan hakları gibi konular işlenmiş olmasına rağmen bu sette bu konulara girilmemiştir. Dolayısıyla konuların çeşitliliği açısından kitap zayıf kalmıştır.

Set dikkatle incelendiğinde, Arap kültürü ile ilgili konulara ve İslam dininin temel ibadetleriyle ilgili parçalara da yer verdiği görülecektir. Örneğin; A2 düzeyinin üçüncü ünitesinde (8. Ders) ünite konusu gündelik hayat olduğu halde, sonda İslam dinindeki iki dini bayramla ilgili bir parça bulunmaktadır. Yine A2 düzeyinin son ünitesinde ünite konusu yeme-içme olduğu halde Ramazan ayı(s.142) onun kutsiyetinden bahsedilmektedir. B1 düzeyinin ilk dersi alış veriş ile ilgili olduğu halde yine içerikte zekat (s.169) konusuyla ilgili bir okuma parçası yer almaktadır. Düzeyin ikinci dersinde de tatille ilgili bir ünite olduğu halde İslam'ın temel ibadetlerinden hac ile ilgili bir metin bulunmaktadır. Daha sonraki ünitede mektuplarım adlı ünite "Berberde" isim konuyla ilgisiz bir metin bulunmaktadır. Yine aynı ünitede "el-Hattu'l-Arabi"(s.197), son ünitede "el-Âlem" konusu işlenirken son tarafta "el-Lehecâtu'l-Arabi”"(s. 220) isimli ilgisiz bir metin bulunmaktadır. Bu metinlerin ünitede işlenen aynı konudan bıktırmamak için konu çeşitliliği açısından konulduğu kanaatindeyiz.

\subsection{Dilbilgisi Konuları ve Dilbilgisi Öğretiminde Kullanılan Yöntem}

Son yıllarda doğrudan dilbilgisi konularını ele alan kitapların terk edilerek dili bir bütün hâlinde ele alan ve Arapçaya bir iletişim dili olarak bakan dil eğitim kitaplarına dönüldüğü görülmektedir. Bu durum, metot olarak Arapçanın iletişim dili olarak öğretilmesinin benimsenmesi olarak da değerlendirebiliriz. Bu yüzden kullanılan serilerin çoğunda doğrudan gramer verilmeyip dilin bizzat kendisi ile yüz yüze getirme şeklinde bir anlayışın benimsendiği görülmektedir. İncelediğimiz "el-Yâsemîn" öğretim setinin de bu metodu benimsediğini ve çok güzel bir şekilde uyguladığını söyleyebiliriz.

"el-Yâsemîn” setinin öğrenci kitabı dilbilgisi açısından incelendiğinde, ilk bakışta konuları özet olarak ele aldığı ve çok fazla örneğe yer vermediği göze çarpmaktadır. Bu durum kitap için bir eksiklik olarak görülebilir ancak bu durum alıştırma kitabında telafi edilmiş ve konularla ilgili her dil becerisini kapsayacak şekilde örneklere ve oyunlara yer verilmiştir. Diğer becerilerde kullanılan tümevarım öğretim yaklaşımının hali hazırdaki yani A1, A2 ve B1 düzeylerinde görememekteyiz. Çünkü konulara baktığımızda bir ünite içerisinde o konuyla ilgili bilinmesi gereken hemen hemen her şey anlattlarak her hangi bir tamamlanacak bölüm kalmamış. Tabi bunun üç düzeyi kapsadığını tekrar vurgulamak da fayda görmekteyiz. Eğer setin diğer düzeyleri de yazılmış olsaydı bu durumu tekrar değerlendirmek gerekebilirdi. Setin dilbilgisi yönteminin diğer setlerden farklilık gösterdiği ve bu konuyla ilgili ayrıca daha geniş bir çalışma yapmamız gerekecektir.

Sonuç olarak, set dilbilgisi konularını çeşitlilik anlamında yeterince işlemiş, konuları alıştırmalar ve dil becerileriyle pekiştirmiş, alışırma kitabında kavramaya yönelik aktivitelerle desteklemiş ve mevcut düzeylerde bütüncül bir yöntem izlemiştir. 


\subsection{Setin İnteraktif Avantajları}

Setin interaktif avantajlarının oldukça fazla olduğu görülmektedir. Seti satın aldığınızda setle beraber size internetten (iarabi.org) adresinden Akademi

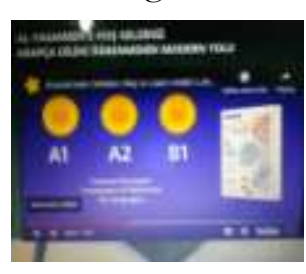

Yasemin'e nasıl gireceğinizi tarif eden bir kart verilmektedir. $\mathrm{Bu}$ siteye girilerek kitabin ses dosyaları dinlenebilir ve videolarını izleyebilir. Ayrıca birçok eğitici materyal buradan indirilebilir. Buna ek olarak, buradan Alşstırma ve ana kitapta olmayan birçok alıştırmaya ulaşılabilir. Yine bu

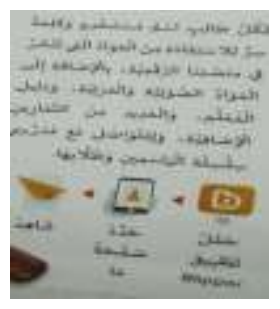
kurulabilir.

Setin alıstırma kitabında her ünitenin bitiminde o ünite ile ilgili bir video bulunmaktadır. Öğrenci şifresiyle "Akademi Yasemin" sayfasına girerek bu

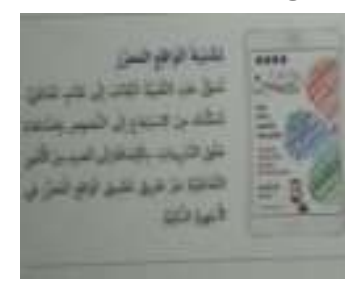
videoları istediği zaman izleyebilir.

Ayrıca öğrenciler "gerçek gerçeklik teknolojisi" yoluyla kitab1 "interaktif kitap" şekline çevirerek

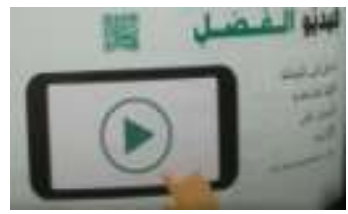
cihazları kullanarak buradan akıllı dinleme metinlerine ve videolara ulaşabilmektedir. Ayrıca öğretmen kitabına pdf olarak yine alyasameen. Net sitesinden ulaşılabilir.

\subsection{Alıştırma Kitabı}

Setin yardımcı materyali olan alışırma kitabı, öğrenci kitabı ile konu ve düzey olarak paralel gitmektedir. Konular görsel malzemeyle desteklenmiş ve alışturma aktiviteleri dört dil becerisini kapsayacak şekilde düzenlenmiştir. Ünitelerde öğrenci kitabında geçen birer paragraflık parçalar harekesiz olarak verilmiş olup bunların harekelenmesi istenmiştir. Kanaatimizce bu fevkalade önemli bir aktivitedir. Çünkü böylece öğrenci hem kelime hazinesini güçlendirecek hem de dilbilgisi kurallarını uygulama firsatı bulacaktır. Öte yandan ünite sonlarındaki beş alı satırdan oluşan âyet-i kerimelerin dinletilmesi ve yazdırılması da telaffuz ve imla bakımından öğrencilere önemli faydalar sağlayacaktır. Bunların yanında her ünitenin sonunda öğrencinin internetten izleyeceği bir videonun ilgili internet adresi verilmiştir. Öğrenci buradan görsel ve işitsel olarak dilini geliştirme imkanına sahip olmaktadır.

Alıştırma kitabında, öğrenci kitabında olmayan okuma parçaları da bulunmaktadır. Bundan amacın, öğrencilerin benzer kelimeler kullanılarak yazılan farklı bir metinle yüz yüze gelmelerini sağlamak olduğu şeklinde değerlendirilmiştir. Öğrenci kitabında olduğu gibi alıştırma kitabında da ünite sonlarında ana kitaptan farklı ve dört dil becerini kavramaya yönelik sınavlar yer almaktadır. Ayrıca dil becerilerini kavramaya yönelik bulmaca ve dilsel oyunları da bu kitapta fazlaca görmek mümkündür. Yine alıştırma kitabında her ünite sonunda "terimler" bölümünü görmekteyiz. Burada terimlerin anlamlarının bulunup birer cümle kurulması istenmektedir ki bu uygulama bir dilin en zor öğretilen kelime grubu olan deyimsel ifadelerin kavranılmasında gerçekten etkili bir yöntem olarak karşımıza çıkmaktadır.

Alıştırma kitabının sonundaki ek sayfaların ilkinde dünya ülkelerini gösteren renkli bir harita bulunmaktadır. Sonraki sayfada, Arapçadaki türetmeyle ilgili bir örnek, tablo şeklinde verilmiştir. Bir diğer sayfada ise, Arapçadaki mezid babaların tablo halinde yer aldığı bir bölüme rastliyoruz. Hemen arkasındaki ek sayfada, konuştukları dillere göre devletlerin dil haritası yer almaktadır. En sondaki ek sayfada ise yine ana kitapta yer alan dil oyunlarıyla ilgili tanıtım bulunmaktadır. 


\section{Sonuç}

Yaptı̆̆ımız çalışmada "el-Yâsemîn” Arapça öğretim seti biçimsel ve yöntemsel olarak incelenmiştir. İnceleme sonucu, setin olumlu yönlerinin olumsuz yönlerinden çok çok fazla olduğu görülmüştür. Kanaatimizce set, iki kitaptan oluşmasına rağmen, bu üç düzey için ciltlerce kitaba gerek olmadığını ortaya koyması anlamında güzel bir örnek teşkil etmektedir. Gerek kelime hazinesi gerekse dilsel aktiviteleri açısından set büyük oranda başarılıdır. Ancak her kitap gibi bu setin de eksik yönlerinin olmasından daha doğal bir şey olamazdi. Setin olumlu ve olumsuz yönlerinin tespitine geçmeden önce setin Avrupa Ortak Dil Çerçeve Metni'ndeki A1, A2, B1 düzeylerindeki konularla (Özcan, 2013:176) uyumlu olduğunu, bunun yazılı olarak setin dış kapak, düzey başlama ve tanıtım sayfalarında yer aldığını ayrıca vurgulamamızda fayda görmekteyiz. Aşağıda, yaptığımız incelemeler sonucu elde ettiğimiz verilere dayanarak setin olumlu ve olumsuz yönleri sıralanmıştır:

\section{1- "el-Yâsemîn" Setinin Olumlu Yönleri}

-Set iki kitaptan oluşmakta, kitapların ebatları taşıma açısından oldukça ideal olup, sağlam bir cilt yapısina sahiptir.

-Kitapların ciltlerinin dış kapaklarında Avrupa Ortak Dil Çerçeve Metni’ndeki A1, A2, B1 düzeyleri yazılmıştır.

-Kitabın taslağı ve planı yeterince açık ve uygundur.

-Ders kitabı görsel açıdan etkili bir şekilde düzenlenmiştir.

-Kitaptaki aktiviteler Arapçada öğretiminde ihtiyacı karşılamaktadır.

-Kitaptaki aktiviteler tek, eşli ve grup olarak çalışmayı sağlıyor.

-Kitapta kullanılan resimler ve fotoğraflar yeni kelimeleri daha rahat

öğrenmeyi sağllyor

-Kitaptaki materyaller dört dil becerisini (okuma, yazma, konuşma ve dinleme) dengeli olarak sunuyor.

-Ders kitabında kullanılan dil gerçek hayatta kullanılan Arapçayı

yansitiyor.

-Kitaptaki dilbilgisi konularının ve kelimelerinin öğretim sırası uygun

şekilde verilmiştir.

-Kitaptaki dilbilgisi konuları kısa ve basit örneklerle sunuluyor.

-Ders kitabının konusu ve içeriği Arapça öğrenen birisi olarak ihtiyaçlarıma uygundur

-Materyallerin konusu ve içeriği yeterince ilginç ve teşvik edicidir.

-becerinin ayrı ayrı sınavla ve kapsamlı bir şekilde test edilmiş olmasıdır ki bu da setin dört beceriye verdiği önemi ortaya koymaktadır

-el-Yasemin" setinin konuşma becerisini geliştirmeye yönelik önemli iki aktivite sunması setin becerileri öğretme yöntemi açısından önemini bir kez daha ortaya koymaktadır.

-Yine alıştırma kitabında her ünite sonunda "terimler" bölümünü görmekteyiz. Burada terimlerin anlamlarının bulunup birer cümle kurulması istenmektedir ki bu uygulama bir dilin en zor öğretilen kelime grubu olan deyimsel ifadelerin kavranılmasında gerçekten etkili bir yöntem olarak karşımıza çıkmaktadır.

-Ünitelerde öğrenci kitabında geçen birer paragraflık parçalar harekesiz olarak verilmiş olup bunların harekelenmesi istenmiştir. Kanaatimizce bu fevkalade önemli bir aktivitedir

-Bunların yanında her ünitenin sonunda öğrencinin internetten izleyeceği bir videonun ilgili internet adresi verilmiştir. Öğrenci buradan görsel ve işitsel olarak dilini geliştirme imkanına sahip olmaktadır.

\section{2- "el-Yâsemîn" Setinin Olumsuz Yönleri}

-Bazı ünitelerde dilbilgisi konuları yoğun bir şekilde ele alındığından öğrenci anlamakta zorluk çekmektedir. 
Set, yazma becerisine diğer aktivitelerden daha az yer vermiştir. Bu üç düzey için bu durum normal de görülebilirse de set için bir eksiklik olarak göze çarpmaktadır.

-Yasemin” Arapça öğretim setinin konularını genel olarak değerlendirmek gerekirse; setin konu çeşidinin diğer setlerdeki aynı düzey konularından daha az olduğu değerlendirilmiştir.

-Setin piyasada kolayca bulunmayışı set için olumsuz bir yön teşkil etmektedir. Setin iki kitabını sadece şu an için İstanbul'da Akdem Yayınları'ndan bulabiliyoruz. Kitapçılarda henüz bulunmamaktadır.

Sonuç olarak, "el-Yâsemîn" öğretim setinin modern bir metotla hazırlanmış, dil becerilerinin öğretilmesinde son derece başarıll, görsel ve işitsel materyali kullanma açısından oldukça zengin, öğrencinin kolayca taşıyabileceği ebatlarda, fiyat olarak oldukça makul, Türkiye şartlarında Arapça öğrenmek isteyenlere diğer setlerden daha fazla yarar sağlayabilecek kanaatindeyiz. ayrıca setin gramer gerekse ve diğer beceriler için ek bir materyale ihtiyacının olduğunu düşünmüyoruz.

\section{6. Öneriler}

Başarılı bir çalışma olduğunu söyleyebileceğimiz setin, yazma becerisine biraz daha yer vermesi, dilbilgisi konulannı özellikle ileriki konularda yoğunlaştırmayıp biraz daha eşit şekilde ünitelere dağıtması, kelimeleri ünitenin girişinde vererek öğrenciyi konuya hazırlaması sayfa düzenindeki birçok yerdeki karmaşıklığı giderecek ayıklamalar yapması kanaatimizce setin başarısı açısından daha faydalı olacaktır. Öte yandan önümüzdeki yıllarda bu setin birçok eğitim kurumu tarafından beğenilerek okunacağı kanaatimizden dolayı ilgililerin bir an önce setin dağıtımını yapmalarının gerekliliğine inanmaktayı.

Ayrıca sette tespit ettiğimiz eksikliklerin giderilmesi ve yaptığımız öneriler çerçevesinde setin tekrar düzenlenmesi, gerekiyorsa bazı ekleme ve çıkarmaların yapılmasının öğretim setinin faydasını bir kat daha artıracağına inanıyoruz.

\section{Kaynakça}

Altun, A. (2017). Türklere Arapşa Ögrretim Teknik ve Yöntemleri. İstanbul. Akdem Yayınlar1.

Balc1, A. (2009). Sosyal Bilimlerde Araştrma. Ankara: Pegem A.

Demiral, H. - Yavuz, Ş. (2016). Türkçenin Yabanc1 Dil Olarak Öğretiminde Ders Diş1 Öğrenme Ortamlar1. Eğitim ve Insani Bilimler Dergisi: Teori ve Uygulama., 7(13), 2016, 129-146.

Demircan, Ö. (1990).Yabanc Dil Ögrretim Yöntemleri. İstanbul: İstanbul Üniversitesi Edebiyat Fakültesi Yay.

Demirel, Ö. (1993). Yabancı Dil Öğretimi. Ankara: Usem Yayınları.

Doğan, C. (1989). Yabancı Dil Olarak Arapça Ögretim Metotlar. Ankara. Yy.

el-Fuzan, A. (2015). İdâat. Konya. Tekin Kitabevi.

el-Hûlî, M.A. (2000). Arap̧̧a Öğretim Metotları. Çev. Cihaner Akçay. Ankara.

Karaduman, A. E. (1992). Yabanc1 Dil Öğretiminde Ders Kitab1 Değerlendirmesi. G.Ü., G.E.F. Dergisi, 8, 319-335.

Karataş, Y. (2001). Türkiye'de Arap̧̧a Öğretimi Açısmdan "Al-Arabiyya li l--Hayat" Ders Kitabınn Değerlendirilmesi. Yayınlanmamış Yüksek Lisans Tezi, Gazi Üniversitesi, Eğitim Bilimleri Enstitüsü.

Küçükahmetl. (2011). Konu Alanı Ders Kitabı Inceleme Kılavu₹u. Ankara: Nobel Yayınları.

Magdi, İ. (2004). Türkiye'de Arapça Öğretimi Açısından "el-Kitabu'l-Esasi”" Serisinin Değerlendirilmesi. Yayınlamamış Yüksek Lisans Tezi., Gazi Üniversitesi, Eğitim Bilimleri Enstitüsü.

Özcan. M. (2013). Arapça Program Geliştirmede “diller İçin Ortk Başvuru Metni”: İlköğretim Arapça Dersi Öğretim Programı Dersi Örneği. Gaæi Üniversitesi Gą̧ Eğitim Fakülttesi Dergisi, 33, 167-182.

Özcan. vd.(2018). Kuramdan Uygulamaya Arap̧a Dil Becerilerinin Öğretimi. İstanbul. Akdem Yayınları. 
Yılmaz, H. (2019). “el-Yâsemîn” isimli Arapça öğretim setinin biçimsel ve yöntemsel açıdan değerlendirilmesi. Journal of Human Sciences, 16(3), 857-874. doi:10.14687/jhs.v16i3.5734

er-Ruhban, A. vd. , (2017). Yabancllara Arap̧sa Öğretimi İcin Arap̧sa Öğretim Rehberi. İstanbul. Akdem Yayınları.

Yanpar, T. T. ve Yıldırım, S. (1999). Ögretim Teknolojileri ve Materyal Gelistirme, Ankara: Anı Yayıncılık.

\section{İnternet siteleri}

abjad@alyasameen.net

badiha.alyasameen.net

huruf.alyasameen.net

İndi.alyasameen.net

jumal.alyasameen.net

kalimat.alyasameen.net

qulli.Alyasameen.net

www.alyasemeen.net

www.iarabi.org

www.iarabi.org

\section{Extended English Summary}

In our study, the "el-Yasemin" Arabic teaching set was examined formally and methodically. The review found that the positive aspects of the set were far too many of the negative aspects. In our opinion, the set is a good example in the sense that although it consists of two books, there is no need for volumes for these three levels. The set is largely successful both in terms of vocabulary and linguistic activities. But like every book, nothing could be more natural than the lack of aspects of this set. Prior to determining the positive and negative aspects of the set, it is also useful to emphasize that the set is compatible with the subjects at levels A1, A2, B1 in the European common language framework text (Özcan, 2013:176) and that it is included in the external cover, level start and introduction pages of the set in writing. Below are the positive and negative aspects of the set based on the data we obtained from our reviews:

\section{1-Positive Aspects of The" el-Yasemin " Set}

- The Set consists of two books, the size of the books is quite ideal in terms of carrying, has a solid skin structure.

- Levels A1, A2, B1 in the European common language framework text are written on the outer covers of the volumes of the books.

- The outline and plan of the book is clear and appropriate enough.

- The textbook is visually effectively edited.

- The activities in the book Meet the need for teaching in Arabic.

- The activities in the book enable us to work as a single, paired and group.

- Pictures and photos used in the book are more comfortable than new words it enables learning

- The materials in the book offer balanced four language skills (reading, writing, speaking and listening).

- The language used in the textbook is Arabic, which is used in real life it reflects.

- The teaching order of grammar subjects and words in the book is appropriate in the manner given.

- Grammar topics in the book are presented with short and simple examples.

- The subject and content of the textbook are appropriate to my needs as a learner of Arabic

- The subject matter and content of the materials are sufficiently interesting and encouraging. 
the skill has been tested separately and comprehensively, which reveals the importance of the set to the four skills

- el-Yasemin " set offers two important activities to improve speech skills, which once again reveals the importance of the set in terms of teaching skills.

- Again, we see the "terms" Section at the end of each unit in the exercise book. This practice is a really effective method of comprehending idiomatic expressions, which are the most difficult-to-teach vocabulary of a language.

- In the units, the pieces of one paragraph in the student's book were given without action and they were requested to be activated. In our opinion, this is an extremely important activity.

- In addition, at the end of each unit, the relevant internet address of a video that the student will watch from the internet is given. The student has the opportunity to develop his / her language visually and audibly.

\section{2-Negative Aspects of The" el-Yasemin " Set}

- Students have difficulty understanding grammar issues in some units.

The Set has given her writing ability less space than other activities. This three-level can be seen at this stage, although it stands out as a shortcoming for the set.

- el-Yasemin " if it is necessary to evaluate the subjects of the Arabic teaching set in general, the subject type of the set is less than the same level subjects in the other sets.

- The fact that the set is not readily available on the market constitutes a negative aspect for the set. Two books of the set can only be found at Akdem publications in Istanbul for the moment. Bookstores are not yet available.

As a result, "Al-Yasemin" were prepared by the method of the instruction set is a modern and extremely successful in the teaching of language skills, visual and sound very rich in terms of material use, the student can easily carry sizes price is quite reasonable, for those who want to learn Arabic in Turkey believe that we can benefit more from the other set. We also do not think that the set needs additional material for grammar or other skills.

\section{Recommendations:}

In our opinion, it is more useful for the success of the set to give a little more space to the writing ability, to concentrate grammar issues especially in the future, to distribute them more evenly to the units, to prepare the student by giving the words at the entrance of the unit, to make extracts that will eliminate the complexity in many places in the page layout. On the other hand, since we believe that this set will be read by many educational institutions in the coming years, we believe that it is necessary for those concerned to distribute the set as soon as possible.

In addition, we believe that eliminating the deficiencies we identified in the set and rearranging the set within the framework of the suggestions we made, adding and removing some of the necessary will increase the benefit of the teaching set one more time. 